\title{
FUTURE MANAGEMENT CHALLENGES IN THE IN THE LIGHT OF ERP IMPLEMENTATION
}

\author{
Mustafa K \\ Head of the Department of Commerce \& Management and Centre of Research, \\ PSMO College, University of Calicut, India
}

\begin{abstract}
Enterprise Resource Planning (ERP) systems support the management in taking timely decisions. Hence it is imperative to ensure implementation success and use ERP systems for the benefit of an organization in the light of managerial effectiveness especially in the future changing scenario where computers, communication, networking and information technology (CCNIT) plays a vital role. It requires raising the managers and administrators to the level of utilising the fruits to the maximum with its huge investment and time consumed. Studies in this area reveal that an organisation can tap only 50\% - 60\% of the facilities available in ERP software and most of the implementations reach in failure.

The present paper makes an attempt to review the dreadful management challenges, identifying the problems likely to be faced by the managers of future and to visualize the likely environmental changes and their impact on management decisions need to be analysed.

The primary data for this study was collected from the experience of management experts from the social networking sites like 'linkedIn' and Google forms.

The future business are likely to be highly automated chip controlled, the softwaredriven man-machine integrated system with artificial intelligence. The current office setup may change and replace by a full-fledged virtual office, in which business is carried through internet facilities like email and web, VoIP \& video call, SMS \& MMS, EDI etc, above the physical barriers. The customers can able to reach $24 \times 7$ days and employer can also reach
\end{abstract}

Key words: ERP: Enterprise Resource Planning.

Cite this Article: Mustafa K. Future Management Challenges in the in the Light of ERP Implementation. International Journal of Advanced Research in Management, 9(1), 2018, pp. 01-10.

http://iaeme.com/Home/issue/IJARM?Volume=9\&Issue=1 


\section{INTRODUCTION}

ERP systems support the management in taking timely decisions for both the internal and external operations of an organization. Hence it is imperative to ensure implementation success and use ERP systems for the benefit of an organization in the light of managerial effectiveness especially in the future changing scenario where computers, communication, networking and information technology (CCNIT) plays a vital role. Installation and maintenance of ERP system is a costly and lengthy affair requiring huge investment, time consuming, vendor consulting, training and system integration. It also requires raising the managers and administrators to the level of utilising the fruits to the maximum with its huge investment and time consumed. Studies in this area reveal that an organisation can tap only 50\% - 60\% of the facilities available in ERP software. As a result, the issues surrounding implementation have been very closely followed by management experts, researchers, both from industry and academia. This study aims to provide background information for future managers in the light of ERP systems use for the organisational effectiveness.

It is certain that the world of today will be different from the world of tomorrow. It is not possible to forecast completely and with full accuracy, the problems which the managers are going to confront in the immediate future, as the future is completely uncertain and turbulent. It may be possible to project the trends and their implications for management of organisations in future. Some of the trends are already visible and some may be predicted to identify the problems which are likely to be faced by the managers of future. The likely environmental changes and their impact on management must be analysed in order to visualize the future management challenges.

\section{STATEMENT OF THE PROBLEM}

It is certain that the world of today will be different from the world of tomorrow. It is completely uncertain and turbulent. Some of the trends are already visible and some may be predicted to identify the problems which are likely to be faced by the managers of future. The likely environmental changes and their impact on management must be analysed in order to visualize the future management challenges.

The current rapidly changing socio-techno environment will continue to change in future also may be in a geometrical progression rate. The future will be turbulent and complex and it would be very difficult for the organisations to cope themselves by predicting exactly and control the consequences of their actions. The organisation lives in a world of competitors, suppliers and customers. It needs to interact or liaison with labour unions, public and governmental agencies. The problems of business combinations in the form of integration and interface will also be of critical importance in future. In future, the environment shall not remain confined to land surface and oceans but would extend to global. He needs to be a technologist, a sociologist and a psychologist. He must indeed to be a rare and balanced composition of scientist and humanist. Thus the future will be proved full of challenge to the managers to work in the multisided changed environment

\section{SCOPE OF THE STUDY}

The present paper makes an attempt to review the dreadful management challenges, identifying the problems likely to be faced by the managers of future and to visualize the likely environmental changes and their impact on management decisions need to be analysed. The manager will have to integrate and coordinate concepts and techniques from several fields. He must have substantial knowledge and competence in both management science and behavioural sciences as well as in ICT. He must be a technologist, a sociologist and a 
psychologist. He must indeed to be a rare and balanced composition of scientist and humanist. The managerial role will offer great rewards for those with a high tolerance for ambiguity and the skills to cope with complex issues in a dynamic and uncertain environment. Thus, this paper makes an attempt to review the present and future management growth and development especially in the ICT environment particularly all organisations are moving towards the implementation of Enterprise Resource Planning (ERP) System for facilitating efficient decision making capability as a part of their Management Information System (MIS).

\section{OBJECTIVES OF THE STUDY}

- To review the dreadful management challenges that a future manager has to face in the light of reports from ERP implementation.

- To identify the problems likely to be faced by the managers of future especially from inefficient use of IT.

- To visualize the likely environmental changes and their impact on management decisions need to be analysed in order to visualize the future management challenges.

\section{RESEARCH METHODOLOGY}

This study is mainly based on secondary data which have been collected from various sources like books, journal articles, seminar and symposium proceedings and paper presentations, $\mathrm{PhD}$ dissertations, management reports of the organisations and other web sources. Primary data from the experience of management experts from the social networking sites like 'linkedIn' was also used.

\section{Management Challenges in the Rapid Changing Environment with the Advent of ERP}

The following are some of the dreadful management challenges that a manager has to face in the rapidly changing environment:

The current rapidly changing socio-techno environment will continue to change in future also may be in a geometrical progression rate. Since the organisations are operating in a turbulent environment, the expansion of science and technology will affect its changing environment. The development of science, information and communication technology emphasizes on educational achievements, and above all by the growing ambitions of people to control their surroundings. Hence it is imperative to ensure implementation success and use ERP systems for the benefit of an organization in the light of managerial effectiveness especially in the future changing scenario where computers, communication, networking and information technology (CCNIT) plays a vital role

The future will be turbulent and complex and it would be very difficult for the organisations to cope themselves by predicting exactly and control the consequences of their actions. The organisation lives in a world of competitors, suppliers and customers. It needs to interact or liaison with labour unions, public and governmental agencies. The problems of business combinations in the form of integration and interface will also be of critical importance in future. In future, the environment shall not remain confined to land surface and oceans but would extend to global. The organisations may be controlled by managers from space stations and undersea cities.

Further changes which may take place in organisations and their environment:

- Global industrializations and modernization 
- Increasing capacity for mass destruction

- Population growth.

- Urbanizations and suburbanization

- Increasing literacy and education as knowledge industry

- Future-oriented thinking, discussion and planning in the light of ICT

- Innovative and manipulative rationality

- Institutionalization of technological changes especially in research, development, innovation and diffusion with ERP

- Increasing universality of the multifold trend

- Increasing tempo of change in all the above

- Reduction in the rate of the digital divide.

- Easy technology transfer

- The emergence of retailing supermarkets and hypermarkets

- Gradual disappearance of small retail shops and distributors

\section{Technological Changes}

This is an era of computers, communication, networking and information technology (CCNIT). Technological changes involve changes in the methods, procedures, equipment and in the large sense, technology-driven methods, procedures, equipment. Technology is changing very fast and new technology is being developed to meet new problems. In 21 century, where the entire infrastructure will be changed, it would be required to develop new technology. Organizations would have to plan their activities keeping in view these changes. Some of the pertinent technological changes probably to influence the management of 21 century are as follows:

\section{Technological Forecasting}

To predict the environment accurately in 21 century, managers would increasingly employ techniques of business forecasting to work out the possible impacts on their activities, e.g. economic forecasts, market forecasts, financial forecasts, political forecasts, international forecasts, and weather forecast as the standard tool of management. In 21 century, especially non-business organisations e.g. Hospitals universities, government agencies etc., will be actively involved in technological forecasting.

\section{Automation}

Growing automation has made the jobs routines. Industrial robots are taking over the factory jobs, the primary tasks of the workers would be to set up production runs, with the programme and control the robots. The present and future business are likely to be highly automated chip controlled, the software-driven man-machine system with artificial intelligence. The current office setup may change and replace by a full-fledged virtual office, in which business is carried through internet facilities like email and web, VoIP \& video call, SMS \& MMS, EDI etc, above the physical barriers. The customers can able to reach $24 \times 7$ days and employer can also reach employees without the time restriction. It will require skilled professionals to discern new scientific development rapidly and convert them into useful tools rapidly. Automation of the manufacturing process will have a major impact on the production, handling, storage, packaging and delivery of products. It is advised to use non-conventional energy, atomic and solar energy in addition to the natural petroleum, coal and water deposits. 


\section{Communication System}

The improved system of communication will be developed to provide quick and latest management information system and assistance to the managers.

\section{Information Technology}

The new technology in the form of information explosion has attacked society in recent time. This technology involves three parts. The first part includes the techniques for electronic data processing (EDP). The second part includes the methods and techniques for analysis of data and includes quantitative methods and management science, operations research and statistical techniques for managerial decision-making. The third part consists of the higher order thinking process like simulation technique through computer software. The integration of all these three parts together constitutes the Enterprise Resource Planning (ERP). Computerised information systems had a revolutionary impact on management. Use of automatic electronic equipment for the collection and processing of data facilitated the fast managerial decision-making process. Improved and innovative use of information technology would be an essential factor in the management in future.

\section{Sociological Changes}

Future, technological innovations will interact with sociological changes and they will influence organisational relationships of employees. For example, automation and rationalization may reduce the level of total employment. Social pressure will require the manager of future to anticipate and stabilize the employment, as employees are demanding increasing say and influence in organisational functioning. In order to meet this demand and to utilise the latent human capability, the managers of future will have to develop more adaptive and humanistic structures in place of traditional bureaucratic mechanistic structure managers of future will face the challenge of striking a delicate and continuing balance between technological improvements and demands of the psycho-social systems.

Some sociological changes in the business environment may be as follows:

\section{Population Trend}

Population explosion will require new markets, new jobs, new methods of production and distribution, new modes of living and several other changes in business methods and operations, some graphics change will tend to increase the average lifespan of the people which will affect the retirement age ratio of composition of workers.

\section{Rise in Education Level}

Increase in literacy will require better leadership. Supervisory training and executive development will become more important as the consumer will become more knowledgeable and conscious, and become more consumer-oriented.

\section{More Leisure Time}

Increasing automation growing affluence and increase in productivity may lead to reduced working hours and four-day work week. Reduced work means multiple jobs for some while for others it requires the development of tourism and entertainment industries. Urbanization, industrialization, standardisation and modernization at the current growth level will lead to fundamental changes norms, culture, civilization, tradition, and social and moral values of the society. Bureaucratic bourgeois and meritocratic cities will develop.

\section{Trend Away from Individualization}

In future people will be growing less independent and more interdependent groups and professional role will increase and individual role will decrease. The trend will be leading towards professionalism, bureaucracy, interdependence between organizations etc. The interdependence and networking will become the management more complex. 


\section{Internationalization of Management}

The changing environment and technologies during the last four decades have impelled organisations to increase their scope and encompass additional activities. A very important form of the ever-changing scope of the organisation is the spread of corporation outside the national boundaries. Such corporations have their homes in one country but operate under the laws, customs and culture of other countries. They are known by different names e.g. Multinational corporations, transnational corporations. The number and size of multinational corporations are increasing and will increase heavily in future. Internationalization of corporations has created new opportunities as well as new problems. Sovereignty and interests of many nations are in danger. Super national regulation and control of the multinational business may be evolved to ensure national sovereignty.

The future may see more geographical and managerial decentralization to overcome language barriers, complex government regulation etc a new crop of international managers will develop to understand and locate market potentials in unfamiliar economic systems. These managers must possess the skill to transfer technical knowhow to different interdependent countries. Thus managers of the future will encounter accelerated growth in the size, scope and complexity of organisations.

\section{Business Government Relations}

When the government brings more control and legal frameworks, the gap and distance are widening. The interface between business and government is likely to increase due to several reasons. Firstly individual employee and consumer cannot bargain on equal terms. Secondly, new technology requires huge investment which is beyond the reach of private entrepreneurs. Thirdly, public opinion is growing and as a welfare state government has to safeguard the public interest.

Increasing intervention and participation of government in business affairs will pose many challenges before management. In many areas, the scope of private enterprises will be reduced and in some other areas, infrastructural facilities will provide new avenues for investment. Organisations will be governed by new laws and regulations. Managers of the future will have to develop skills for effective interaction with the government. Mutual cooperation between public and private sectors for tapping unutilized resources will result in more joint sector enterprises. Public financial institutions will advise, guide and regulate private sector enterprises, business will have to work with the state to shape national policies for national development.

\section{Growing Complexity of Decisions}

Decision-making will become more complex and sophisticated in future on account of two reasons; firstly, use of computerised information systems and other sophisticated techniques will provide more and better information to managers. Secondly, various groups both inside and outside the organisation (trade unions, consumers association, suppliers, public financial institutions etc.) will demand greater power and influence in the decision making process. Managers will have to keep in mind the interest of these groups while making decisions.

\section{Obsolescence: A Managerial Experience}

The future manager will have been to constantly frustrate because of the out of fashion and obsolescence of experience. This is true because of the managerial climate change so quickly that outstanding solutions to problems in the past may be miserable failures in the present or future. No doubt, with the accelerating change in technology, knowledge is declining with too much dependence on technology. 
To face this challenge, the managers of 21 century will have to continually renew and upgrade their knowledge themselves with proper orientation and refresher training programmes. They will have to undergo special full time or part time executive development programmes conducted by educational and professional institutions. Managers of the future will have to become behavioural scientists. They will be required to read current management literature to keep in touch with the latest developments. They will be granted study leave to obtain post-experience training and thereby renew their knowledge.

\section{Management Tasks}

In order to successfully face the new challenges of the future, managers will have to modify their modes operations and to respond to ongoing changes. Successful managers will be those who can react quickly to the new demands and who can modify their approach to make the best use of the opportunities. New principles and practices will have to be developed and the existing ones may require modification. The modified tasks of the managers of future will be as follows:

\section{Business Forecasting}

Management will have to do technological forecasting to avoid blocking up capital in those technologies which are going to be obsolete very soon. Social forecasting will be required to anticipate expected trends in the value systems of people.

\section{Initiative and Creativity}

The manager of the future will have to take more initiative than his predecessors. He will also be more original and creative so as to generate several ideas quickly.

\section{Management by Objectives}

The managers of future will have to manage and appraise by objectives.

\section{Trusteeship}

The manager of the future will have to serve as trustee for various stakeholders like investors consumers, employees, government and the community.

\section{Systems Approach}

The new environments will demand that managers understand and manage their firms as integral parts of the socio-economic systems.

\section{Information Management}

The collection, storage, processing and transmission of information will be an important organisational function in future.

\section{Involvement in Community Affairs}

The manager of future will have to participate actively in community affairs; he will have to give his time and funds for educational institutions, local programmes of community development, pollution control, urban development, political programmes etc. This is in addition to the corporate social responsibility.

\section{The manager of future will have to be an antenna of his firm}

The manager of future will have to pick up messages from the public and to communicate effectively the policy of his firm to outside world.

\section{Human Relations}

With the increase in education and self-consciousness, management will have to provide jobs that offer self-fulfillment and participation. The future manager must be able to build an integrated team each member of which is capable of setting his own goals and measuring his own results. Labour will be treated as a capital investment than a current cost. To motivate and utilise this new brand of employees, management will have to provide innovative and 
creative work which provides the feeling of achievement. The human assets will appear on the balance sheets of the future. Some of the organisations are showing human resources as a powerful asset and shown as an asset in the Financial statements. Future managers will be evaluated on their ability to use human talent than capital.

\section{Strategic Decision-Making}

The future office executives will have to work fully under uncertainty and take strategic decisions. They need to acquire and develop a full-fledged complete set of tools for decisionmaking today in order to cope with the changing needs of tomorrow.

\section{Management Principles Needed in Future}

The principle of management of perception-management should have the ability to perceive future political and social trends and determine their impact on the organisation so as to improve future performance.

\section{The Principle of Social Responsibility}

The focus of this principle is identifying and analysing those social forces which have an impact on the organisation so that they can be integrated within organisation objectives and plans to meet social challenges now and in the future.

\section{Principle of effective organisations development}

Effective organisation development should focus on economic goals that are reducing the cost of manpower turnover, and absenteeism as well as improving operational efficiency and performance.

\section{Principle of effective management information system}

Present ERP system provides utilization management which is able to extract relevant information from the management information system, particularly real-time MIS, to control present and future operations.

\section{Principle of effective employee utilization}

The present style is the participative management and workers participation in management. It requires integrating all employees into their position. This principle allows reservations for women and minority groups into managerial positions. Both state government and central government are cautious about this in order to fulfill the legal requirements.

\section{CONCLUSIONS}

The manager of future will have to integrate and coordinate concepts and techniques from several fields. He must have substantial knowledge and competence in both management science and behavioural sciences as well as in ICT. He must be a technologist, a sociologist and a psychologist. He must indeed to be a rare and balanced composition of scientist and humanist. Despite growing challenges and complexities, future holds many promises for managers. The managerial role will offer great rewards for those with a high tolerance for ambiguity and the skills to cope with complex issues in a dynamic and uncertain environment. However, the new challenges and tasks do not mean that the future manager will be a superman. In the words of Peter Drucker, "the manager of tomorrow will not be a bigger man than his father was before him".

Thus the future will be proved full of challenge to the managers to work in the multisided changed environment. 


\section{REFERENCES}

[1] Drucker, P. F. (2007). Management challenges for the 21st century. Routledge.

[2] Sharma, P., Chrisman, J. J., \& Chua, J. H. (1997). Strategic management of the family business: Past research and future challenges. Family business review, 10(1), 1-35.

[3] Toth, E. L. (Ed.). (2009).The future of excellence in public relations and communication management: Challenges for the next generation. Routledge.

[4] Ahlemann, F., Stettiner, E., Messerschmidt, M., \& Legner, C. (Eds.). (2012). Strategic enterprise architecture management: challenges, best practices, and future developments. Springer Science \& Business Media.

[5] Jarvenpaa, S. L., \& Ives, B. (1994). The global network organization of the future: Information management opportunities and challenges. Journal of management information systems, 10(4), 25-57.

[6] Hamel, G. (2008). The future of management. Human Resource Management International Digest, 16(6).

[7] van Meerbeeck, J. P., Scherpereel, A., Surmont, V. F., \& Baas, P. (2011). Malignant pleural mesothelioma: the standard of care and challenges for future management. Critical reviews in oncology/hematology, 78(2), 92-111.

[8] Van de Vrande, V., De Jong, J. P., Vanhaverbeke, W., \& De Rochemont, M. (2009). Open innovation in SMEs: Trends, motives and management challenges. Technovation, 29(6-7), 423-437.

[9] Boin, A., \& Lagadec, P. (2000). Preparing for the future: critical challenges in crisis management. Journal of contingencies and crisis management, 8(4), 185-191.

[10] Pettigrew, A. M., Woodman, R. W., \& Cameron, K. S. (2001). Studying organizational change and development: Challenges for future research. Academy of management journal, 44(4), 697-713.

[11] Pettigrew, A. M., Woodman, R. W., \& Cameron, K. S. (2001). Studying organizational change and development: Challenges for future research. Academy of management journal, 44(4), 697-713.

[12] Allen, C. R., Fontaine, J. J., Pope, K. L., \& Garmestani, A. S. (2011). Adaptive management for a turbulent future. Journal of environmental management, 92(5), 1339- 1345.

[13] Lewis, P. S., Goodman, S. H., \& Fandt, P. M. (2000). Management challenges in the 21st century. South-Western Pub.

[14] Barkema, H. G., Baum, J. A., \& Mannix, E. A. (2002). Management challenges in a new time. Academy of Management Journal, 45(5), 916-930.

[15] Schoemaker, P. J. (2008). The future challenges of business: Rethinking management education. California Management Review, 50(3), 119-139.

[16] Riccucci, N. M. (Ed.). (2017). Public personnel management: Current concerns, future challenges. Routledge.

[17] Vidgen, R., Shaw, S., \& Grant, D. B. (2017). Management challenges in creating value from business analytics. European Journal of Operational Research, 261(2), 626-639.

[18] Vidgen, R., Shaw, S., \& Grant, D. B. (2017). Management challenges in creating value from business analytics. European Journal of Operational Research, 261(2), 626-639. 
[19] Schultz, M. J., Dunser, M. W., Dondorp, A. M., Adhikari, N. K., Iyer, S., Kwizera, A., .\& Angus, D. C. (2017). Current challenges in the management of sepsis in ICUs in resourcepoor settings and suggestions for the future. Intensive care medicine, 43(5), 612-624.

[20] Schmitt, A., Raisch, S., \& Volberda, H. W. (2018). Strategic renewal: past research, theoretical tensions and future challenges. International Journal of Management Reviews, 20(1), 81-98.

[21] Benton, Lewis (ed ) Management for the Future. New York, McGraw Hill, 1978. Cleveland, Harlen, The Future Executive, New York; Harper and Row 1972.

[22] Drucker, Peter F, Managing in Turbulent Times; London, Hememann 1980. Farmer, R.N., Management in the Future, Belmount, Wadsworth, 1967,

[23] Gupta, C. B., Principles and Practice of Management, National Publishing House, New Delhi.

[24] Hicks, Herbert G. and C. Ray Gullett, Management. New York; McGraw Hill, 1981.

[25] Toffler Alvin, Future Shock, New York; Random House, 1970.

[26] Peter Drucker, "The Practice of Management" 